\title{
Soil geochemical survey over concealed kimberlites in the Attawapiskat area in northern Canada
}

\author{
Keiko H. Hattori ${ }^{1, *}$, Stewart Hamilton ${ }^{2}$, Julie Kong ${ }^{3}$ \& John Gravel ${ }^{4}$ \\ ${ }^{1}$ Department of Earth Sciences, University of Ottawa, Ottawa, Ontario, K1N 6N5, Canada \\ ${ }^{2}$ Sedimentary Geoscience Division, Ontario Geological Survey, Sudbury, Ontario, P3E 2G9, Canada \\ ${ }^{3}$ DeBeers Canada Inc., 65 Overlea Blvd., Toronto, Ontario, K4H 1P1, Canada \\ ${ }^{4}$ Acme Analytical Laboratory, 1020 Cordova St. East, Vancouver, British Columbia, V6A 4A3, Canada \\ *Corresponding author (e-mail: khattori@uottawa.ca)
}

\begin{abstract}
A soil geochemical survey was conducted over kimberlites in a discontinuous permafrost zone in the James Bay Lowlands, southeastern Hudson Bay Lowlands. The kimberlites are concealed by 10 to $30 \mathrm{~m}$ of tills and Tyrell Sea clay sediments. Samples of humus and B-horizon soil were collected at 25-50-m intervals over traverses with the total lengths of $562 \mathrm{~m}$ over the Whiskey kimberlite and $740 \mathrm{~m}$ over the Yankee kimberlite pipe. B-horizon soil samples, sieved to $<80$ mesh and dried at $60^{\circ} \mathrm{C}$, have high carbonate contents above the margins of the kimberlite pipes. Ammonium acetate leach at $\mathrm{pH} 5$ (AA5) dissolves most of these carbonates, and shows anomalies of REE, $\mathrm{Y}$ and $\mathrm{Ni}$ above the margins instead of the centres of kimberlites. Since the leach dissolves not only carbonates but also amorphous Al-O-OH originating from the clastic component, the ratios of metals to $\mathrm{Al}$ are effective to display geochemical anomalies associated with kimberlites. The concentrations of high field strength elements, such as $\mathrm{Nb}$ and $\mathrm{Ta}$, are low in AA5 relative to their detection limits, whereas these elements show anomalies in the Enzyme leach. The ratios of these metals to $\mathrm{Mn}$ in the Enzyme leach are useful to display the anomalies associated with kimberlites because soil samples over kimberlites contain high contents of these metals and low contents of Mn. Our data suggest that a soil geochemical survey may be used to assist in discriminating kimberlites from other targets during diamond exploration in sub-Arctic settings.
\end{abstract}

KEYWORDS: surface dispersion, surficial geochemical exploration, James Bay Lowlands, soil geochemistry, diamond, Canadian Shield, partial leach

Archean shield terranes have the potential to host diamond deposits, since diamond crystallizes in the thick lithospheric mantle underlying ancient shields. Despite this favourable geology, large areas of Archean shields in northern countries have not been tested for the presence of kimberlites, partly because they are covered by swamps and overburden. At present, two techniques are most commonly employed in diamond exploration in northern countries: mapping of indicator minerals and geophysical surveys. The distribution of indicator minerals in basal tills and streams provides a vector for diamondiferous rocks (e.g. Fipke et al. 1995; McClenaghan et al. 2000), but the potential source areas could be huge, more than several hundred kilometres along the flow direction of glaciers. Geophysical techniques may identify buried kimberlites, but many mafic and ultramafic rocks unrelated to kimberlites commonly yield geophysical signals similar to kimberlites. Furthermore, some diamondiferous kimberlites may not necessarily show magnetic anomalies (e.g. Power et al. 2004).

The chemical compositions of kimberlites are markedly different from most other crustal rocks. Kimberlites have high contents of alkalis and light rare earth elements (REE), and high field strength elements (HFSE), such as Nb and Ta
(Fig. 1), and they also have high concentrations of refractory elements, such as $\mathrm{Mg}, \mathrm{Cr}$ and Ni. Therefore, their distinct chemical compositions may be detected in surface media over concealed kimberlites. To examine the feasibility of surficial

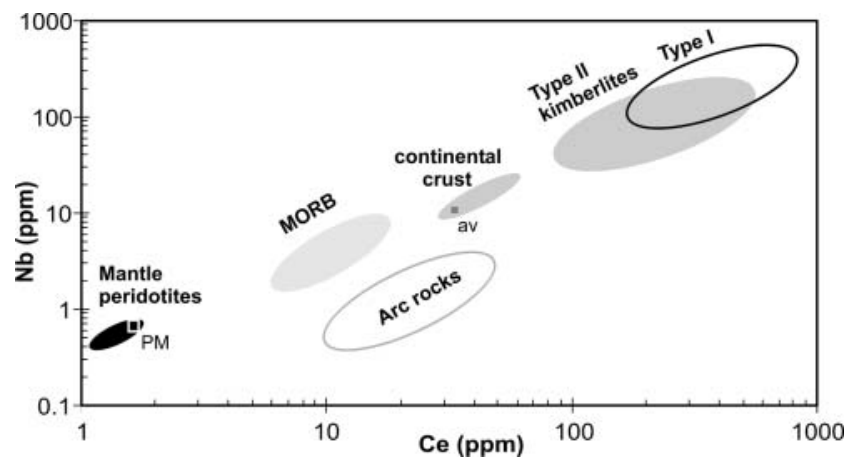

Fig. 1. General geochemical characteristics of kimberlites in comparison with peridotites, oceanic basalts (MORB), continental crust, and arc rocks. The data sources are primitive mantle composition (PM, McDonough \& Sun 1995), MORB (Klein 2005), continental crust (Taylor \& McLennan 1995), and kimberlites (Mitchell 1986). 


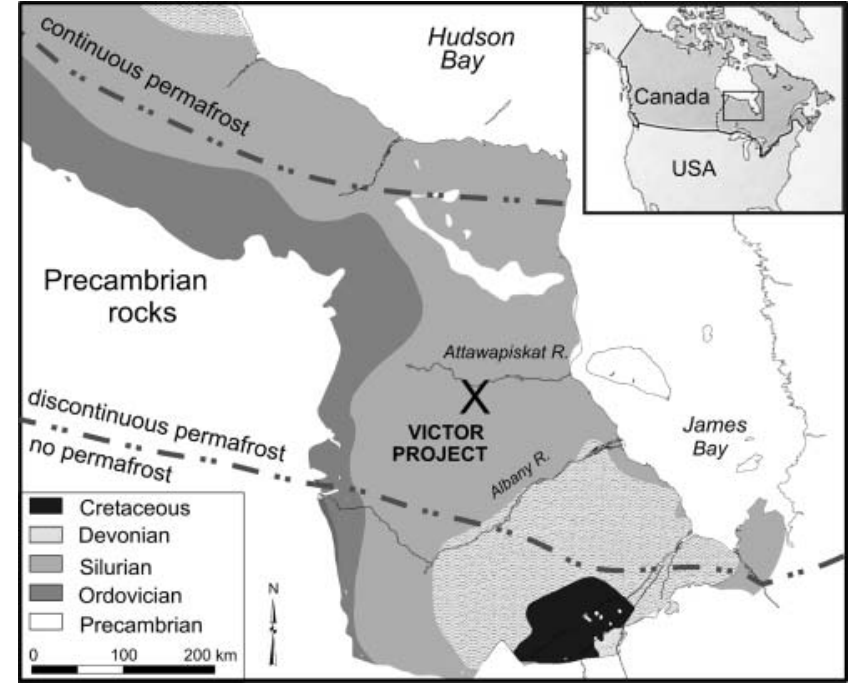

Fig. 2. Map showing the study area and geology of the James Bay Lowlands. Modified after Fowler et al. (2001) and Webb et al. (2004).

geochemical exploration for kimberlites, we selected the Attawapiskat field in the James Bay Lowlands (Fig. 2). The study area contains at least 19 kimberlites; although the mining started from the Victor pipe in the spring of 2008, other kimberlites are undisturbed, and are overlain by Quaternary tills, clay sediments, peat and swamps. There is a ground covering of peat except above the two kimberlites. This paper reports the geochemical data of soil overlying the two kimberlite pipes from the Attawapiskat area and discusses the use of soil anomalies in kimberlite exploration.

\section{PREVIOUS SOIL GEOCHEMICAL WORK IN KIMBERLITE EXPLORATION}

There are many geochemical studies of kimberlite indicator minerals in tills and streams applied to diamond exploration (e.g. Fipke et al. 1995), but few studies have been carried out on soil geochemistry in glaciated terranes. These previous soil geochemical surveys have been conducted by provincial and federal government institutions in Canada and reported in their publications (e.g. Burt \& Hamilton 2004; Seneshen et al. 2005; Fenton et al. 2006). The results of these exploratory surveys vary from encouraging to disappointing; the mixed results may have contributed to the limited use of soil geochemical surveys by the mineral exploration industry.

Seneshen et al. (2005) conducted extensive surveys of a variety of surface media including plants and bogs from three kimberlite fields of northern Alberta: Mountain Lake, Buffalo Head Hills and Birch Mountains. They identified Ni, Co, Cu, $\mathrm{Cr}, \mathrm{Ti}, \mathrm{V}, \mathrm{Mg}, \mathrm{Mn}$ and $\mathrm{Fe}$ as 'the primary element associated' with kimberlites and $\mathrm{Nb}, \mathrm{Rb}, \mathrm{Zr}, \mathrm{Y}, \mathrm{Sc}$, Th, U, Cs, REE, P, Al, $\mathrm{K}, \mathrm{Na}, \mathrm{Ca}, \mathrm{Ba}, \mathrm{Sn}, \mathrm{Mo}, \mathrm{W}, \mathrm{Cd}, \mathrm{Zn}, \mathrm{Pb}, \mathrm{B}, \mathrm{Hf}$, and $\mathrm{Ga}$ as 'the secondary element association'. Total digestion and Enzyme leach of soil samples show anomalous concentrations but the anomalies do not necessarily occur above kimberlites. The lack of spatial correlations of soil anomalies directly over kimberlites, expected by the authors, led them to recommend a total digestion of spruce as the most cost-effective method in exploration for concealed kimberlites.

Fenton et al. (2006) conducted total to near-total digestion of humus, B-horizon and C-horizon soil samples from the kimberlite field in northern Alberta, where there is up to a $20-\mathrm{m}$ thick till cover. Although they found elevated concentrations of selected kimberlite pathfinder elements, such as $\mathrm{Mg}$, $\mathrm{Ni}$ and $\mathrm{Cr}$, in mineral soils, they too could not find a good spatial relationship between kimberlite pipes and the concentrations of pathfinder elements in soil because they too assumed that the strongest anomalies should be in the centres of areas over kimberlites.

Burt \& Hamilton (2004) conducted an Enzyme leach analysis of soil samples over the centres of kimberlites in the Kirkland Lake area. They did not find clear differences in concentrations of pathfinder elements between areas directly over and outside kimberlites. For example, light REE values are slightly high above the centre of the A-4 kimberlite compared to the background areas, but not at the Diamond Lake kimberlite. Niobium did not show any difference between the interiors and exteriors of the soils studied over these kimberlites (Burt \& Hamilton 2004).

McClenaghan et al. (2006) collected soil and peat samples along traverses over kimberlites, including those studied by Burt \& Hamilton (2004). These samples were analysed by two partial leach methods: AA5 and Mobile Metal Ions ${ }^{\text {SM }}$ (MMI). They found broad positive correlations of element concentrations $(\mathrm{Ca}, \mathrm{Mg}, \mathrm{Zn}, \mathrm{Cd}, \mathrm{Pb}$ etc) in the $\mathrm{AA} 5$ and the organic carbon contents, and suggested a role of organic matter in metal accumulation. At the same time, they pointed out high metal contents in organic-poor mineral soil samples compared to organic-rich soil in wet sites along traverses over kimberlites, and noted the importance of collecting similar media.

\section{STUDY AREA}

The study area is in the zone of discontinuous permafrost (Fig. 2). Frozen ground was detected at a depth of $c .60 \mathrm{~cm}$ at several sites during field work in August, 2007. The average temperature of the area is slightly above freezing, with a moderate precipitation of $c .650 \mathrm{~mm} / \mathrm{a}$. (http://www.climate. weatheroffice.ec.gc.ca/climate_normals/index_e.html).

\section{General geology}

The area is covered by flat-lying Paleozoic limestones that overlie the c. 3.0 billion year old Archean rocks of the Superior geological province (Fowler et al. 2001; Fig. 2). The total thickness of limestone beds is typically $250 \mathrm{~m}$ and reaches 300 m. Explosive kimberlitic magmas intruded Archean rocks and overlying limestones at $c .170 \mathrm{Ma}$, producing pyroclastic rocks over limestones and fall-back kimberlite pipes (Webb et al. 2004). Subsequent weathering and erosion removed the pyroclastic rocks and upper parts of the pipes. The remaining pipes were later covered by Quaternary glaciers and tills (Fig. 3). The retreat of the Laurentide Ice Sheet allowed the incursion of sea water and deposition of Tyrell Sea clayey sediments 8000-4400 years ago (Fig. 3). Isostatic rebound of the continent has lifted the area above sea level, and the uplift is still continuing to the present.

\section{Access to the study area}

The Victor mine site is located $90 \mathrm{~km}$ west of coastal community of Attawapiskat, Ontario. The area has land access only during several winter months using ice roads. Year-round access to the mine site is possible by air using an airstrip near the Victor mine site. The Victor mine site is surrounded by bogs and swamps. Therefore, field work over other kimberlites required a helicopter. 


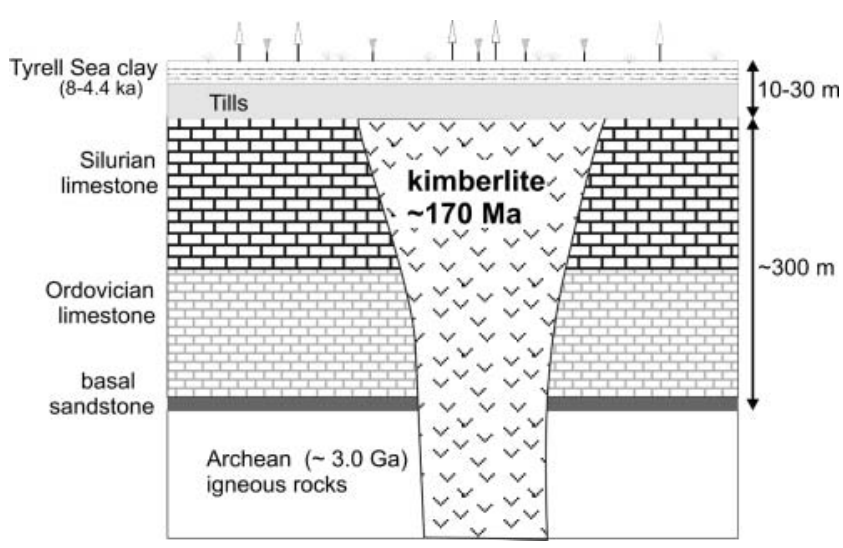

Fig. 3. A schematic diagram showing the vertical section of units hosting kimberlites and overburden in the study area. Kimberlites intruded Archean rocks and Palaeozoic limestone beds at c. 170 Ma. They were later covered by Quaternary tills and Tyrell Sea clayey sediments at 8000-4400 years. Modified after Webb et al. (2004).

\section{Kimberlites}

Almost all kimberlites are concealed, except for small outcrops of the Zulu kimberlite, and the Uniform kimberlite. The latter is exposed on the north shore of the Attawapiskat River. To date, 19 kimberlites have been found on the DeBeers property over an area of $c .10 \mathrm{~km} \times 15 \mathrm{~km}$, and 17 are diamondiferous (Fowler et al. 2001). The Victor kimberlite pipe is the largest among them with a surface area of $15 \mathrm{ha}$; open-pit mining of the pipe commenced in the spring of 2008 .

We collected soil samples over the Whiskey and Yankee kimberlite pipes (Table 1). Both pipes are volcaniclastic macrocrystalline kimberlites. The Yankee pipe, c. $5.2 \mathrm{~km}$ south from the mine site, has a projected surface area of 3.9 ha and a long axis of $270 \mathrm{~m}$, oriented NW-SE. It is covered by c. $10 \mathrm{~m}$ of overburden, tills and Tyrrell Sea clayey sediments. The Whiskey kimberlite, $2 \mathrm{~km}$ SE from the mine site, has a projected surface area of $2.7 \mathrm{ha}$, with the long axis of $300 \mathrm{~m}$ oriented ESEWNW. It is overlain by 6 to $10 \mathrm{~m}$ of tills and Tyrrell Sea clayey sediments. The surface areas of both sites are covered by shrubs and spruce trees (Figs. 4a, b), with the soil surface consisting of leaves, partially decayed branches of wood, and sphagnum moss. The Whiskey site has more trees than the Yankee site. The outlines of the kimberlites are well defined (Figs. 5a, b) by prominent positive ground magnetic anomalies compared to non-magnetic limestones.

\section{Selection of sampling sites}

Surficial geochemical anomalies over concealed mineral deposits are commonly offset from the centres of deposits, and some are located over the edges of deposits (e.g. Bajc 1998; Hamilton 1998; Smee 1998; Cokers 2007). Sampling along a traverse is designed to collect samples from positions over the margins, as well as the centre, of a concealed deposit. In addition, traverse sampling allows the collection of local background samples from the ends of a traverse as far as it is sufficiently long. Therefore, we collected samples along traverses over the locations of the kimberlites and into background areas (Fig. 5a, b).

The traverses were selected to collect similar surface media along similar topography with similar vegetation at $25-50-\mathrm{m}$ intervals. The intervals of sampling were $c .25 \mathrm{~m}$ near the edges of the underlying kimberlite pipes. The total length of traverses were $562 \mathrm{~m}$ over the Whiskey kimberlite and $740 \mathrm{~m}$ over the Yankee kimberlite. The lengths of traverses were decided by
Table 1. Sampling locations in NAD 83, Zone 17.

\begin{tabular}{lccc}
\hline \multicolumn{2}{l}{ Whiskey Traverse, kimberlite: $147-274 \mathrm{~m}$} & \\
& easting & northing & distance (m) \\
\hline W1 & 307079 & 5854993 & 0 \\
W2 & 307057 & 5854940 & 57 \\
W3 & 307035 & 5854891 & 111 \\
W4 & 307027 & 5854867 & 136 \\
W5 & 307012 & 5854846 & 162 \\
W6 & 306994 & 5854825 & 190 \\
W7 & 306980 & 5854800 & 219 \\
W8 & 306968 & 5854776 & 245 \\
W9 & 306955 & 5854752 & 276 \\
W10 & 306945 & 5854728 & 305 \\
W11 & 306928 & 5854705 & 339 \\
W12 & 306907 & 5854656 & 396 \\
W13 & 306891 & 5854604 & 451 \\
W14 & 306871 & 5854554 & 507 \\
W15 & 306856 & 5854502 & 562 \\
\hline
\end{tabular}

Yankee Dry Traverse, kimberlite 252-378 m

\begin{tabular}{lrrr}
\hline YD1 & 306049 & 5851012 & 0 \\
YD2 & 306089 & 5851025 & 42 \\
YD3 & 306144 & 5851059 & 107 \\
YD4 & 306194 & 5851062 & 156 \\
YD5 & 306252 & 5851067 & 214 \\
YD6 & 306273 & 5851085 & 242 \\
YD7 & 306299 & 5851108 & 277 \\
YD8 & 306325 & 5851146 & 323 \\
YD9 & 306350 & 5851191 & 374 \\
YD10 & 306352 & 5851213 & 396 \\
YD11 & 306392 & 5851256 & 455 \\
YD12 & 306430 & 5851295 & 510 \\
YD13 & 306435 & 5851340 & 556 \\
YD14 & 306437 & 5851395 & 610 \\
YD15 & 306429 & 5851447 & 662 \\
YD16 & 306398 & 5851491 & 716 \\
YD17 & 306379 & 5851474 & 742 \\
\hline
\end{tabular}

several factors, including surface condition and the availability of time in the field.

\section{SAMPLING AND ANALYSIS}

\section{Sample collection}

Humus layers at the sample sites vary in thickness from $5 \mathrm{~cm}$ to $45 \mathrm{~cm}$ and B-horizon from $5 \mathrm{~cm}$ to $15 \mathrm{~cm}$. Grey leached layers are present below the humus layers, but they rarely exceed $2 \mathrm{~cm}$ in thickness. Samples of humus, c. $200 \mathrm{~g}$, and B-horizon soil, c. $500 \mathrm{~g}$, were collected at each station using a hand-held Dutch auger, and placed in plastic freezer bags. Humus samples were collected after removing the top layer of organic litter by gloved hand, and B-horizon soil samples were collected in the uppermost $10 \mathrm{~cm}$ directly below the leached zone. Humus was not collected when it was not well developed. Samples from over the Whiskey kimberlite were collected in July, 2006 and those from over the Yankee kimberlite in September, 2006.

A soil slurry was made on the day of sampling by mixing soil samples with approximately equal amounts of deionized water in disposable plastic vials. The values of $\mathrm{pH}$, oxidationreduction potential and electronic conductivity were recorded.

\section{Laboratory analysis}

Samples of both humus and B-horizon soil were air-dried at temperatures below $60^{\circ} \mathrm{C}$, disaggregated, and sieved to $<80$ mesh $(<0.19 \mathrm{~mm})$. Samples were heated stepwise from $105^{\circ} \mathrm{C}$, $350^{\circ} \mathrm{C}, 550^{\circ} \mathrm{C}$ and $900^{\circ} \mathrm{C}$. The loss on ignition (LOI) at each 

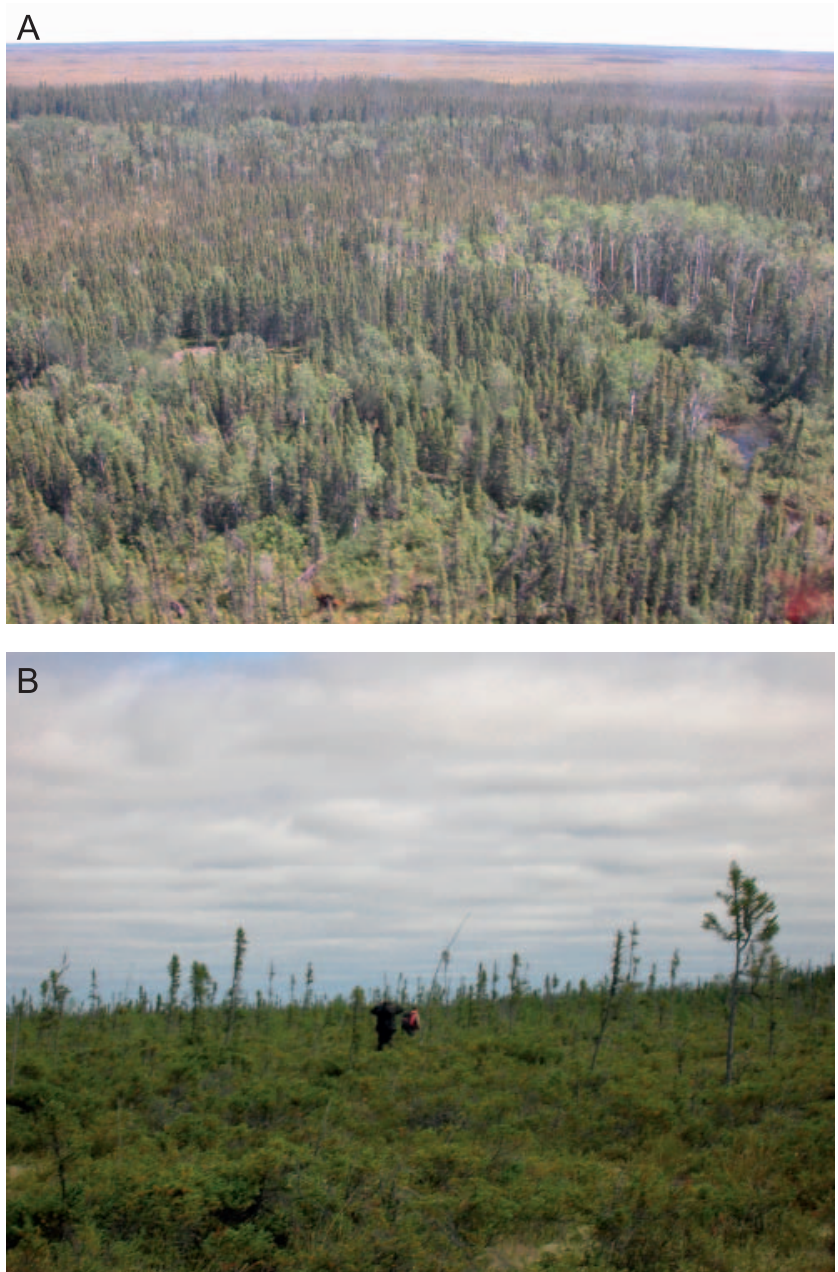

Fig. 4. (A) The area overlying the Whiskey kimberlite and (B) the Yankee kimberlite. The area over the Whiskey kimberlite is covered by spruce trees, whereas the area over the Yankee kimberlite has shorter trees and shrubs.

temperature is recorded as $\mathrm{LOI}_{105^{\circ} \mathrm{C}} \mathrm{LOI}_{350^{\circ} \mathrm{C}}, \mathrm{LOI}_{550^{\circ} \mathrm{C}}$ and $\mathrm{LOI}_{900^{\circ} \mathrm{C}}$. The LOI was determined because previous workers pointed out the possible contribution of organic matter to metal concentrations above kimberlites (McClenaghan et al. 2006).

Soil samples were subjected to near-total digestion using hot $\mathrm{HF}+\mathrm{HNO}_{3}+\mathrm{HClO}_{4}+\mathrm{HCl}$, plus two partial leaches. One is an ammonium acetate leach at $\mathrm{pH} 5$ (AA5) (e.g. Cave \& Harmon 1997). One gram of sample is soaked in $10 \mathrm{ml}$ of $1 \mathrm{M}$ ammonium acetate for $1 \mathrm{~h}$ and the leach solution is decanted after centrifuging the solution for $5 \mathrm{~min}$ at $2400 \mathrm{rpm}$. The residue is rinsed with $10 \mathrm{ml}$ of water and the centrifugation is repeated to obtain $c .20 \mathrm{ml}$ of clean solution. The composition of the solution was determined with by ICP-MS. The second leach is the Enzyme leach, which utilizes a reaction between glucose oxidase and dextrose to produce a low concentration (c. $20 \mathrm{ppm}$ ) of $\mathrm{H}_{2} \mathrm{O}_{2}$ solution to partially leach metals associated with amorphous $\mathrm{Mn}-\mathrm{O}-\mathrm{OH}$ (Clark 1993).

\section{RESULTS}

\section{Near-total digestion data}

Organic matter is decomposed at $550^{\circ} \mathrm{C}$ and $\mathrm{CO}_{2}$ in carbonates at $900^{\circ} \mathrm{C}$ (Heiri et al. 2001). Therefore, $\mathrm{LOI}_{350^{\circ} \mathrm{C}}$ plus $\mathrm{LOI}_{550^{\circ} \mathrm{C}}$ are considered to represent organic contents. The values of $\left(\mathrm{LOI}_{350^{\circ} \mathrm{C}}+\mathrm{LOI}_{550^{\circ} \mathrm{C}}\right)$ in humus are high, up to $78 \mathrm{wt} \%$. Those
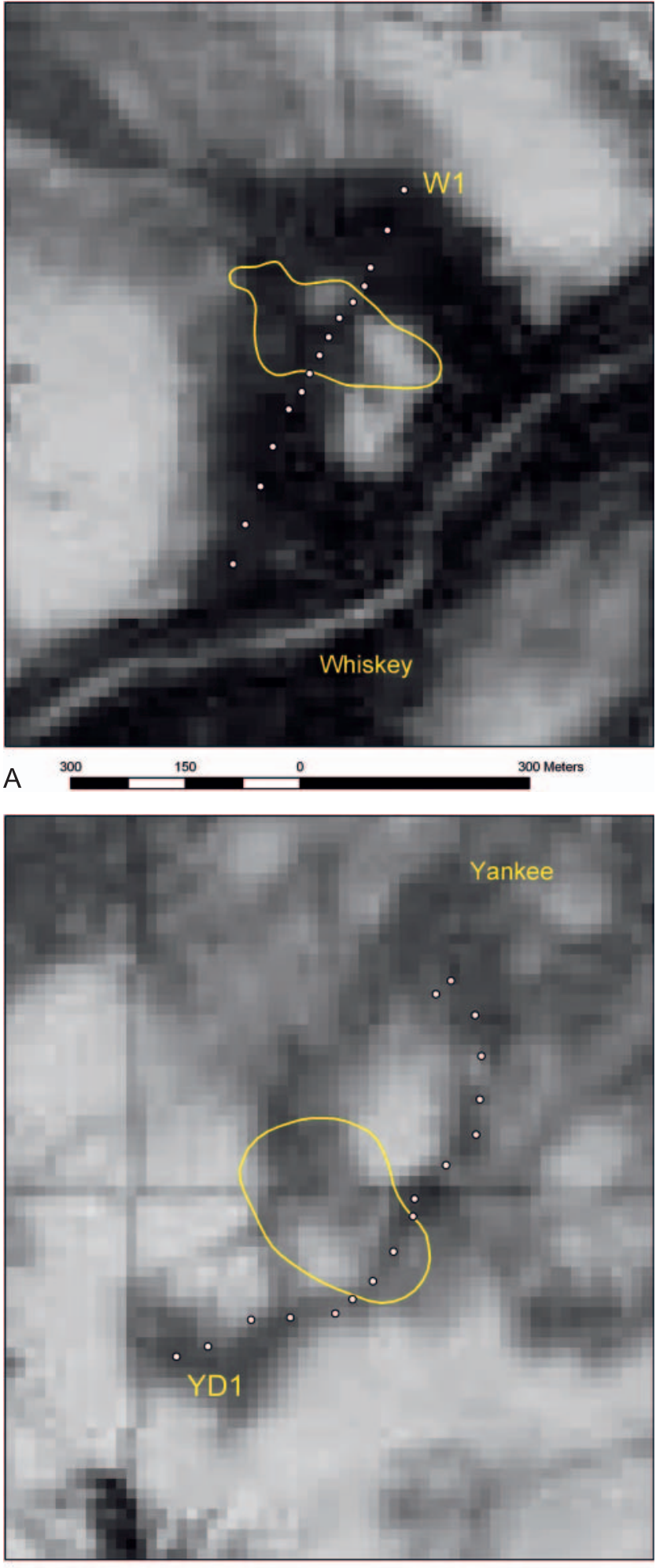

B 300

150

300 Meters

Fig. 5. Sample locations over kimberlites shown in the satellite photographs with treed areas being dark. The Whiskey traverse trends from the NE to the SW over the kimberlite (5a) and the Yankee traverse trends from SW to NE. Sampling sites are listed in Table 1.

for B-horizon soil samples from the Whiskey Traverse range from 2.3 to $5.1 \mathrm{wt} \%$, whereas those from the Yankee Traverse range from 4.4 to $16 \mathrm{wt} \%$. 


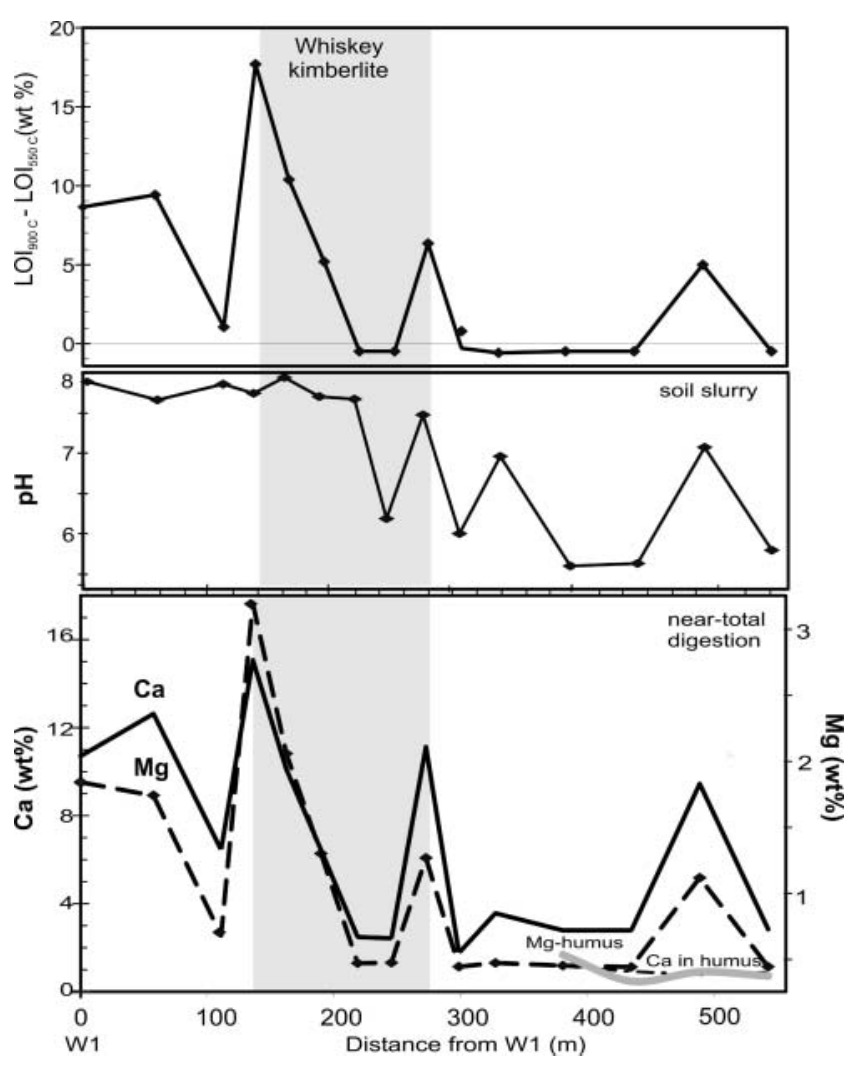

Fig. 6. The amounts of carbonates in B-horizon soil expressed as $\left(\mathrm{LOI}_{900^{\circ} \mathrm{C}}-\mathrm{LOI}_{550^{\circ} \mathrm{C}}\right)$ and $\mathrm{Ca}$ and $\mathrm{Mg}$ contents in near-total digestion of B-horizon soil and humus along the Whiskey traverse, and $\mathrm{pH}$ of soil slurry (1:1 mixture of soil and distilled water). The amounts of $\mathrm{CaCO}_{3}$ calculated from $\mathrm{Ca}$ and $\mathrm{CO}_{2}$ contents are similar, confirming that most $\mathrm{Ca}$ is in $\mathrm{CaCO}_{3}$. Note that $\mathrm{Ca}$ contents (dashed line) and $\mathrm{Mg}$ contents (thick gray line) in humus are much lower than those in B-horizon soil. The area over the kimberlite is shown in gray.

The contents of $\mathrm{CO}_{2}$, expressed as $\mathrm{LOI}_{900^{\circ} \mathrm{C}}$, vary from 0.16 to $19.4 \mathrm{wt} \%$, which correspond to 0.4 to $44 \mathrm{wt}^{\%} \mathrm{CaCO}_{3}$ in the soil samples. High carbonate contents are observed in soil samples overlying the margins of kimberlites along the traverses (Fig. 6). The crystallization of secondary carbonates is supported by high contents of $\mathrm{Ca}$ (up to $15 \mathrm{wt} \%$ ) and $\mathrm{Mg}$ (up to $2.7 \mathrm{wt}^{\mathrm{0}} \%$ ) in near-total digestion of soil samples over the margins of the kimberlite (Fig. 6). The amounts of $\mathrm{CaCO}_{3}$ calculated from $\mathrm{Ca}$ contents are similar to those estimated from $\mathrm{LOI}_{900^{\circ} \mathrm{C}}$, suggesting that most $\mathrm{Ca}$ is hosted by carbonates. The contents of $\mathrm{Mg}$ show a large variation in carbonates (Fig. 7). A plot of $\mathrm{Mg} / \mathrm{Ca}$ vs the recovery of $\mathrm{Ca}$ in AA5 (Ca in AA5/Ca in near-total digestion) indicate that high- $\mathrm{Mg}$ carbonates are not dissolved in AA5 (Fig. 7).

The solubility of carbonates is dependent on $\mathrm{pH}$ in a system with no addition of $\mathrm{Ca}$ and $\mathrm{CO}_{3}{ }^{2-}$, thus it is commonly considered that carbonate precipitates in response to a $\mathrm{pH}$ increase. In our samples, the contents of secondary carbonates do not necessarily correlate with $\mathrm{pH}$ (Fig. 6). For example, the soil slurry $\mathrm{pH}$ values in the northeastern part of the Whiskey traverse, W1 to $\mathrm{W} 7$, are $c .7$ with little variation; however, the highest $\mathrm{CaCO}_{3}$ content is recorded at the site $\mathrm{W} 4$, above the northern margin of the kimberlite pipe (Fig. 6). High content of $\mathrm{CaCO}_{3}$ at the site was confirmed also in the fall when selected sites are resampled. The data suggest that the secondary carbonates near the site over the margin of the kimberlite precipitate not in direct response to $\mathrm{pH}$ change. Instead, the precipitation is most likely due to an addition of $\mathrm{CO}_{2}$.

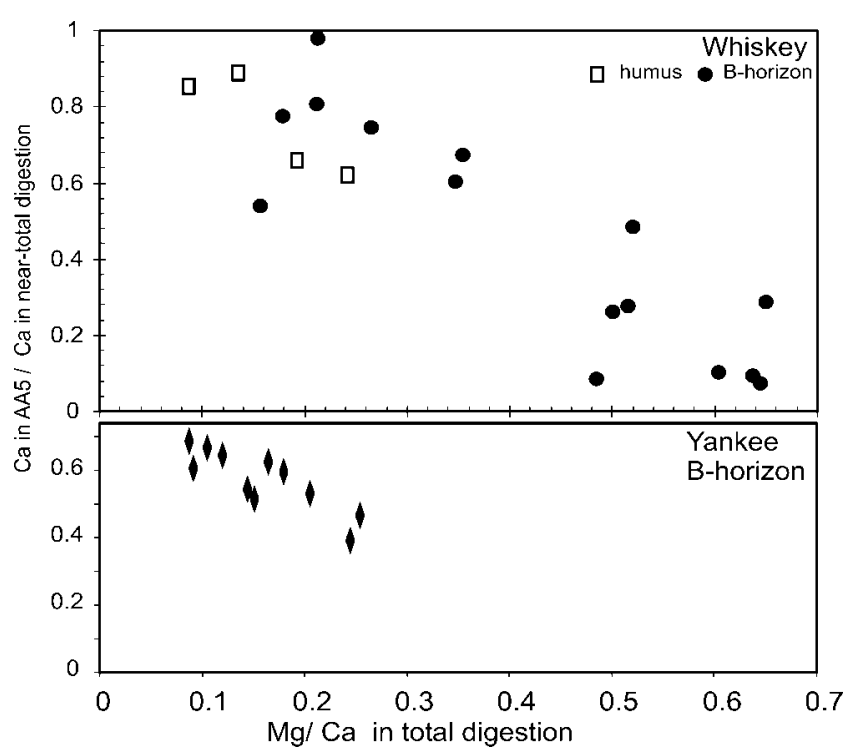

Fig. 7. The recovery of carbonates in $\mathrm{AA} 5 \mathrm{vs} . \mathrm{Mg} / \mathrm{Ca}$ ratios of soil samples, expressed as the ratios of $(\mathrm{Ca}$ in $\mathrm{AA} 5$ ) to $(\mathrm{Ca}$ in total digestion). Calcium in samples is largely hosted by carbonates, expressed as $\mathrm{CaCO}_{3}$ contents based on LOI data. Lower recovery in samples with high $\mathrm{Mg}$ indicates that AA5 dissolves $\mathrm{CaCO}_{3}$, but not $\mathrm{Mg}$-rich carbonates.

The data after near-total digestion show a considerable variation in Fe and Mn contents. The contents are overlapping, but low values occur in the areas over the kimberlites. For example, samples from the area over the Whiskey kimberlite contain 2.2-2.6 $\mathrm{wt}^{\%} \% \mathrm{Fe}$ and 263-350 $\mathrm{ppm} \mathrm{Mn}$, whereas samples from the areas outside the pipe contain over $3 \mathrm{wt} \% \mathrm{Fe}$ and $400 \mathrm{ppm} \mathrm{Mn}$.

\section{Acetate leach (AA5)}

The AA5 leach shows high contents of rare earth elements (REE) and $\mathrm{Ni}$ above the margins of the studied kimberlites (Figs. 8a, 8b, 9 \& 10), displaying similar concentration patterns as carbonate contents along traverses. Significant concentrations of REE and $\mathrm{Ni}$ are present in backgound areas, but the ratios of $\mathrm{REE} / \mathrm{Al}$ and $\mathrm{Ni} / \mathrm{Al}$ are less prominent outside the kimberlite (Figs. 8a, 8b, 9 \& 10).

Kimberlites are characterized by high concentrations of light REE, but also high field strength elements (HFSE), such as Nb and $\mathrm{Ta}$ (Fig. 1). Since these highly charged elements are generally low in crustal rocks, their concentrations may be useful as kimberlite pathfinder elements, but anomalies of HFSE are not apparent in AA5. Their concentrations in the AA5 leach solutions are overall low, up to $15 \mathrm{ppb} \mathrm{Nb}$ in the Whiskey traverse and up to $29 \mathrm{ppb} \mathrm{Nb}$ in the Yankee traverse. Niobium contents at most sites are below the detection limit of $10 \mathrm{ppb} \mathrm{Nb}$. All sites yielded Ta contents in AA5 below the detection limit of $20 \mathrm{ppb}$. The lack of anomalies in the AA5 leach may be partially attributed to their high detection limits. In addition, these pentavalent metals are not incorporated in carbonates, and thus do not readily dissolve in AA5. Therefore, these metals recorded in AA5 are those loosely held in soil samples.

\section{Enzyme leach}

To extract highly charged elements, we employed an Enzyme leach of B-horizon soil samples as charged metals are known to be extracted in Enzyme leach (e.g. Gray et al. 2001). The results 

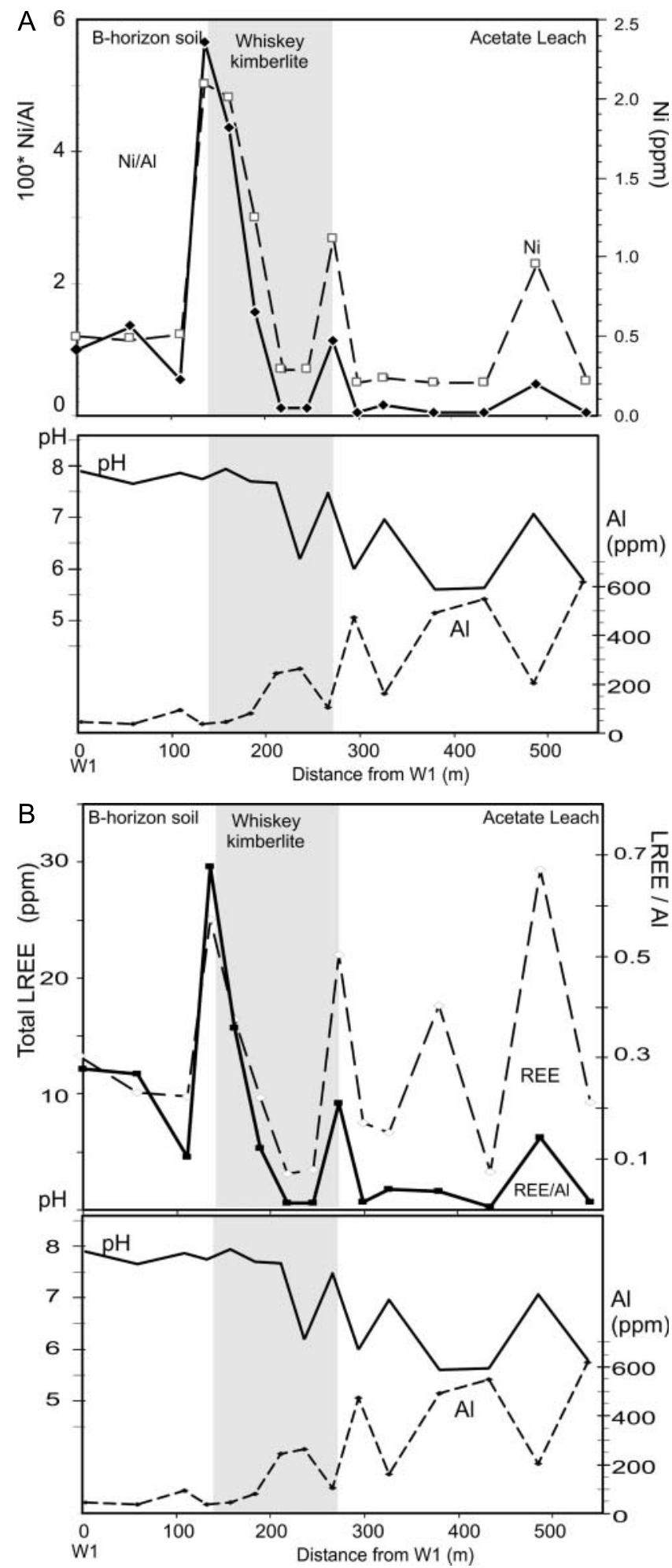

Fig. 8. (A) The ratios of $\mathrm{Ni} / \mathrm{Al}$ (solid line) and $\mathrm{Ni}$ contents compared to soil slurry $\mathrm{pH}$ and $\mathrm{Al}$ contents along the Whiskey traverse. (B) The sum of the concentrations in light REE and the ratios of $\mathrm{REE} / \mathrm{Al}$ compared to soil slurry $\mathrm{pH}$ and $\mathrm{Al}$ contents in the AA5 leach along the Whiskey traverse.

show peaks of $\mathrm{Nb}$ and $\mathrm{Ta}$ concentrations above kimberlites. The data appear to suggest that the Enzyme leach dissolves such charged elements, but the absolute contents of $\mathrm{Nb}$ in the Enzyme leach are comparable to those in AA5. For example, $\mathrm{Nb}$ contents in Enzyme leach from B-horizon soil at the sites W7 and W8 are 19 and 16 ppb, respectively. The two samples

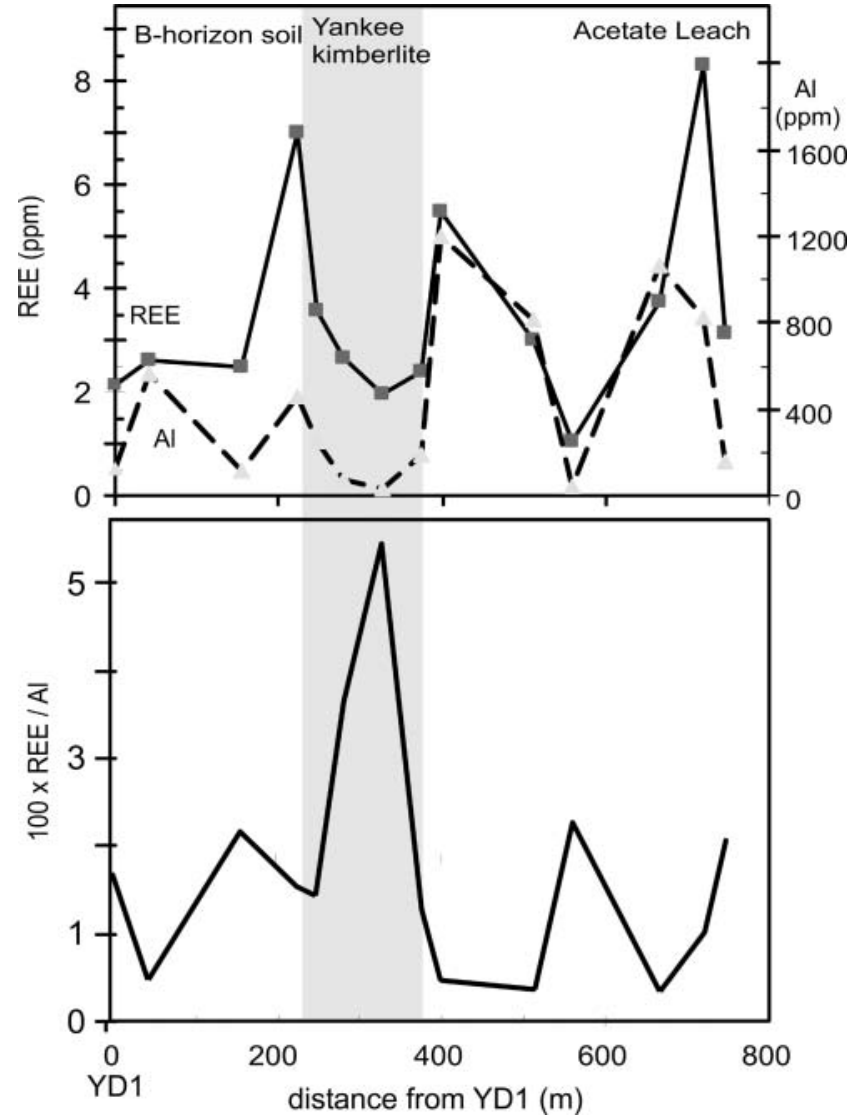

Fig. 9. Sum of REE (solid line, left axis) and $\mathrm{Al}$ contents (dashed line, right axis, upper diagram) in upper diagram and the ratios of $\mathrm{REE} / \mathrm{Al}$ (lower diagram). All results are the contents in the AA5 leach of B-horizon soil along the Yankee traverse.

yielded $12 \mathrm{ppb}$ and the value below the detection limit of 10 ppb, respectively, in AA5. The presence of anomalies in the Enzyme leach may be partially explained by the low detection limits of $\mathrm{Nb}$ and $\mathrm{Ta} ; 0.1 \mathrm{ppb}$ and $0.02 \mathrm{ppb}$, respectively. High detection limits of these elements in AA5 may possibly masked the anomalies over the kimberlite.

It has been known that the ratios of metals to $\mathrm{Mn}$ in the Enzyme leach enhance anomalies over concealed deposits (e.g. Yeager et al. 1998; Williams \& Gunn 2002). Therefore, the ratios of pathfinder elements to $\mathrm{Mn}$ are plotted along traverses over kimberlites. The ratios of $(\mathrm{Nb}+\mathrm{Ta}) / \mathrm{Mn}, \mathrm{REE} / \mathrm{Mn}$, $\mathrm{Ti} / \mathrm{Mn}$ and $\mathrm{Cr} / \mathrm{Mn}$ indeed show anomalies over the kimberlites (Figs. 11a, b \& 12). The reason for apparent anomalies is discussed below.

\section{DISCUSSION}

Medium for a surficial geochemical survey

Humus samples contain high contents of organic matter, and low concentrations of almost all metals compared to B-horizon soil at any given site (Fig. 6). Therefore, the metal concentrations in partial leach solutions from humus are also low (Fig. 10).

McClenaghan et al. (2006) found broad positive correlations between organic carbon and metal contents, including $\mathrm{Ca}, \mathrm{Mg}$, $\mathrm{Sr}, \mathrm{Pb}, \mathrm{Zn}, \mathrm{U}$, and $\mathrm{Cd}$, in B-horizon soil and organic-rich soil (humus and peat). In our samples, we did not find any correlations between metals and organic contents. Instead, humus samples contain markedly low contents of metals (Figs. $6 \& 10$ ) probably because they are 'diluted' by organics. 


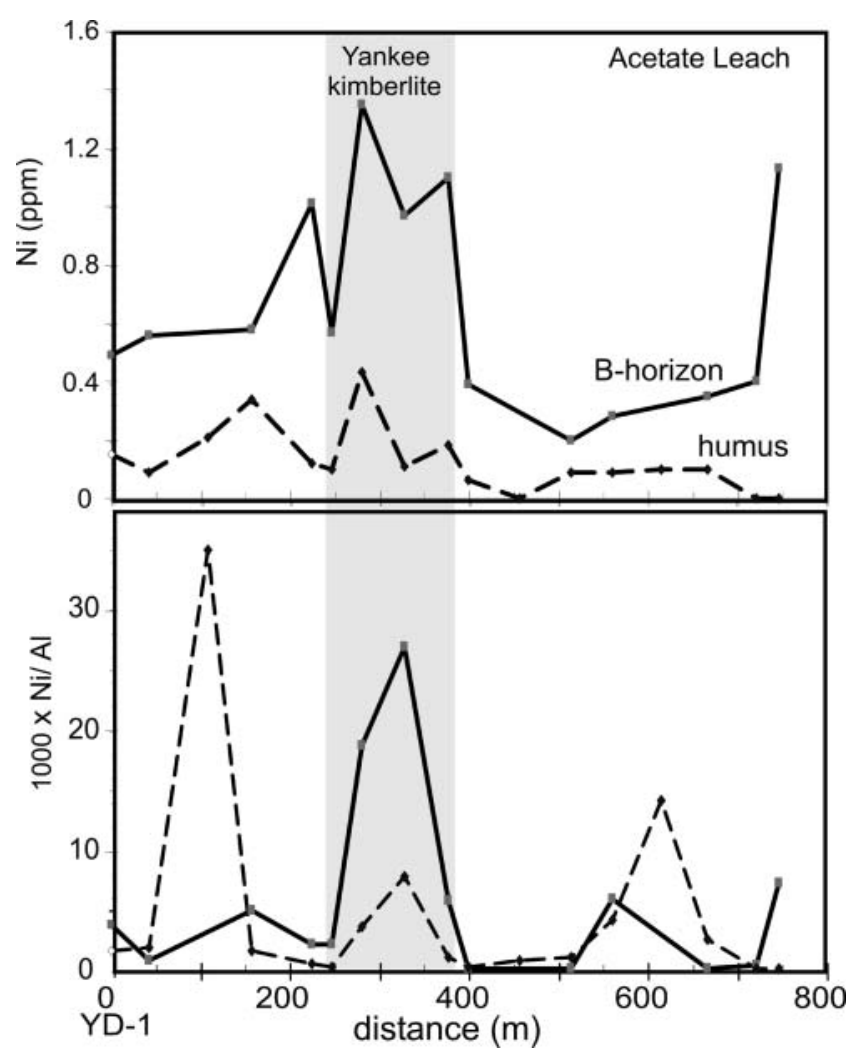

Fig. 10. Nickel contents and ratios of $\mathrm{Ni} / \mathrm{Al}$ in $\mathrm{AA} 5$ in $\mathrm{B}$-horizon soil (solid lines) and humus (dashed lines) along the Yankee traverse. The samples of B-horizon soil contain greater concentrations of $\mathrm{Ni}$ than samples of humus at a given site.

The reason for the positive correlations found by McClenaghan et al. (2006) is not certain except for P because it is an essential nutrient of plants and expected to be high in organics. Most of these metals listed by McClenaghan et al (2006) are not necessarily kimberlite pathfinder elements. Therefore, we suggest that B-horizon soil is a better medium than humus in detecting kimberlite geochemical signatures during exploration, if B-horizon soil is available. Large differences in the concentrations of metals between humus and B-horizon soil samples suggest that it is important to collect similar media of samples along a traverse.

We sieved soil samples to $<80$ mesh for laboratory analysis, following the conventional analytical technique of soil samples; the secondary phases are all fine grained. It is possible that finer fractions of samples may yield better signals of kimberlites, but a further study is required to evaluate the optimal size fraction of soil samples.

\section{Partial leach}

Various partial leach techniques have been developed in the past (e.g. Bajc 1998; Cameron et al. 2004; Kelley et al. 2004, 2006). The results of the AA5 leach suggest that it is effective in showing the anomalies of kimberlite pathfinder elements, including REE, $\mathrm{Y}$, and Ni. The concentrations of total REE in the AA5 solutions is up to $>30$ ppm in soil samples (Fig. 8b). These elements also show anomalies in the Enzyme leach, with the maximum contents of total REE exceeding $600 \mathrm{ppb}$ (Fig. 11b). These REE form cations in surface solutions, such as $\mathrm{Y}^{3+}$ and $\mathrm{Ce}^{4+}$, and such charged cations should be adsorbed onto the surface of amorphous Fe-Mn-O-OH, but they also have a strong affinity with $\mathrm{CO}_{3}{ }^{2-}$ (Luo \& Byrne 1998).

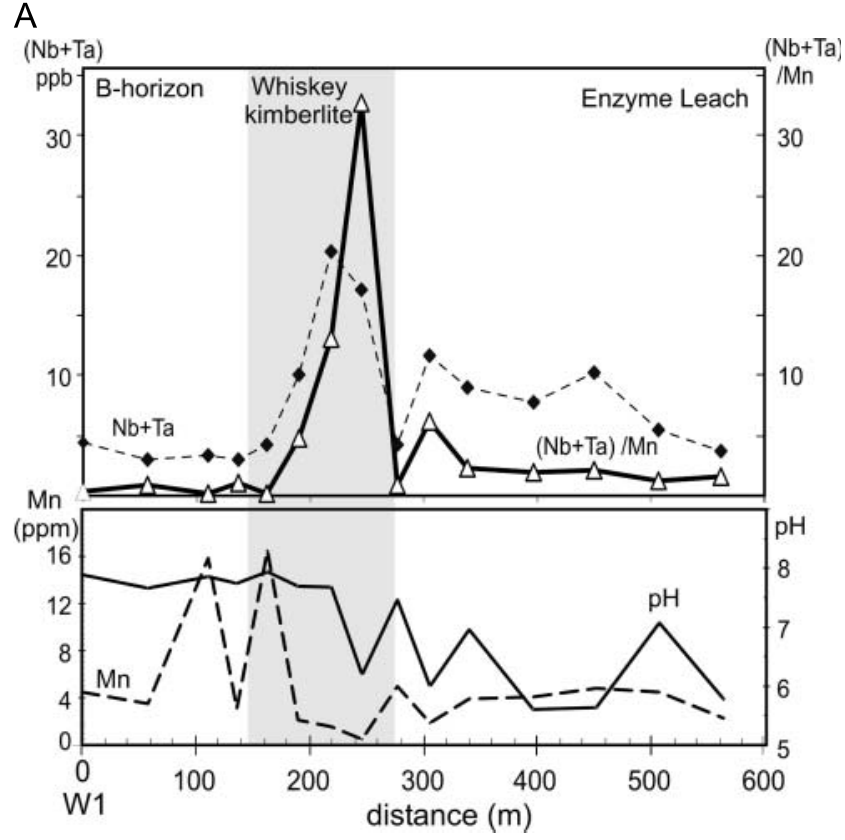

B

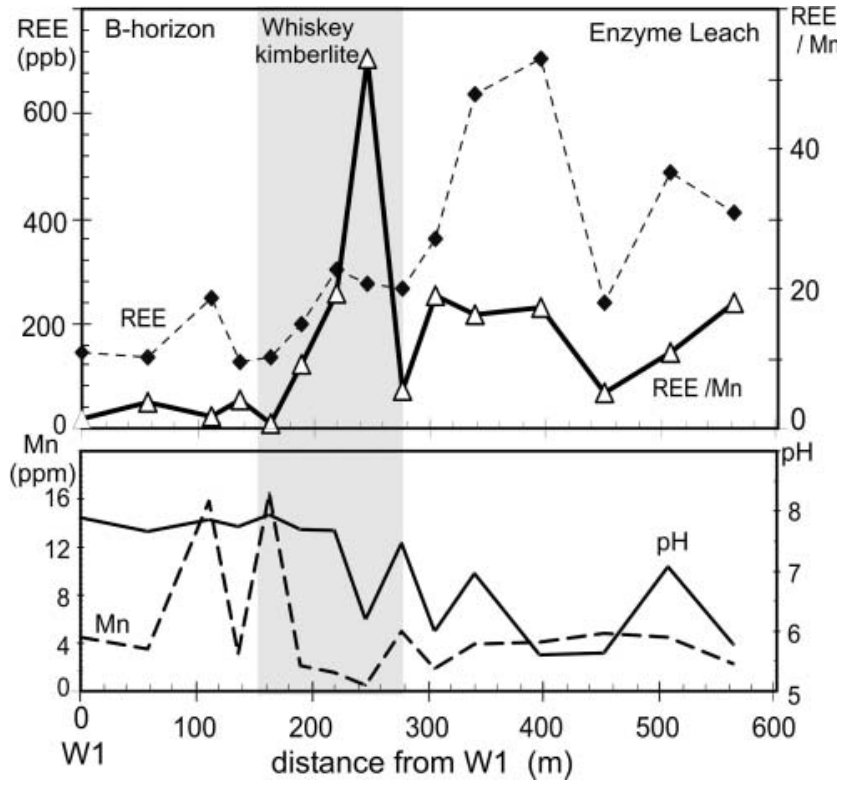

Fig. 11. (A) Enzyme leach results of B-horizon soil over the Whiskey traverse. Sum of $\mathrm{Nb}+\mathrm{Ta}$ (dashed line, left axis) compared to the ratios of $(\mathrm{Nb}+\mathrm{Ta}) / \mathrm{Mn}$ (solid line, right axis, upper diagram) together with $\mathrm{Mn}$ contents (dashed line, left axis), and soil slurry $\mathrm{pH}$ (solid line, right axis, lower diagram). (B) Sum of REE (dashed line, left axis) and the ratios of REE/Mn (solid line, right axis, upper diagram) compared to the contents of $\mathrm{Mn}$ (dashed line, left axis), and soil-slurry $\mathrm{pH}$ (solid line, right axis, lower diagram). Both for Enzyme leach over the Whiskey traverse.

Therefore, these elements are incorporated in secondary carbonates and dissolved in AA5, whereas the Enzyme leach does not dissolve carbonates and therefore the concentrations are less prominent.

Partial extraction techniques work on the premise that metals released from deposits are transported upwards to surface media and these 'exogenic' elements are adsorbed or bound in the secondary phases in soil, such as organic matter, Fe-O-OH, Mn-O-OH, and clay minerals (e.g. Bajc 1998; Kelley et al. 2004; Cameron et al. 2004). Partial leaches would allow the 


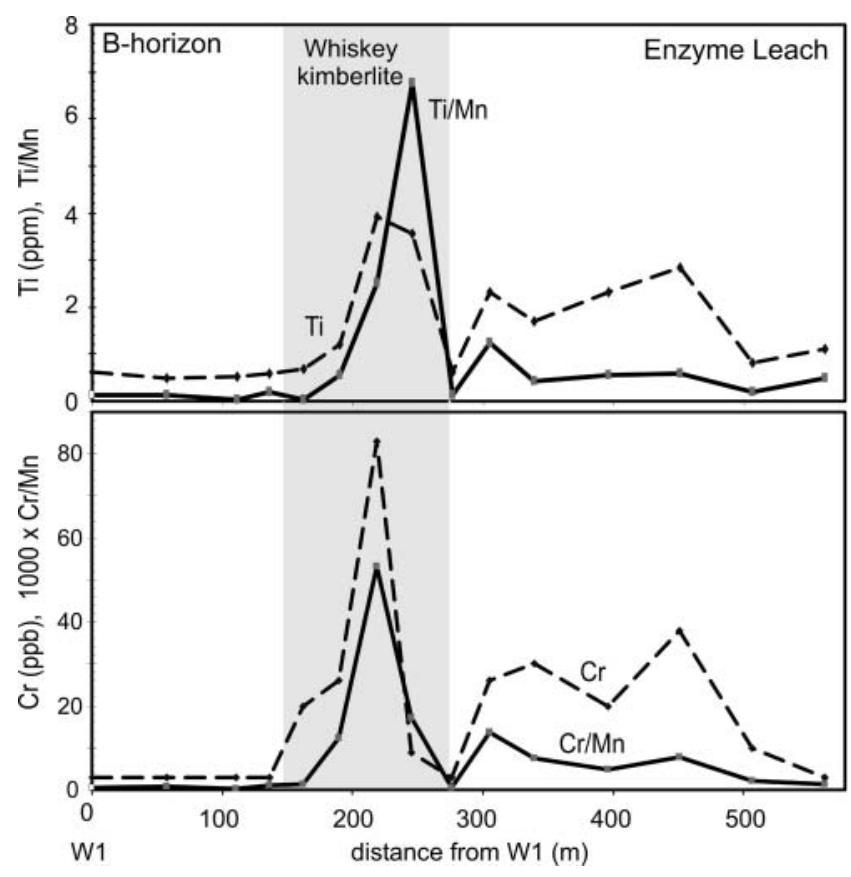

Fig. 12. Contents of $\mathrm{Ti}$ (dashed) and the ratios of $\mathrm{Ti} / \mathrm{Mn}$ and the contents of $\mathrm{Cr}$ (dashed) and the ratios of $\mathrm{Cr} / \mathrm{Mn}$ in the Enzyme leach along the traverse over the Whiskey kimberlite.

dissolution of elements adsorbed or bound in a specific target phase(s) while not dissolving the entire soil. Therefore, the amounts of elements from clastic components are minimized in leach solutions so that the solutions give lower detection limits of elements. Low detection limits and little dissolution of clastic components should create a greater contrast of signal-to-noise ratios of pathfinder elements in the leach solutions between anomalous and barren areas. An ideal leach dissolves only elements that are introduced to the soil from the underlying deposits ('exogenic origin') without affecting the clastic component of soil itself ('endogenic origin'); however, leach solutions may dissolve phases other than target phases because soil is a mixture of poorly crystalline solids, and amorphous colloids, such as Al-O-OH and Fe-O-OH. It also contains loosely held elements on the surfaces of minerals and trapped between layers of clay minerals. Therefore, leach results need to be carefully evaluated for possible 'endogenic' contribution of elements.

\section{Ammonium acetate leach}

The ammonium acetate leach is designed to dissolve carbonates (e.g. Wakefield 1980; Filipek \& Theobald 1981). The comparison of elements leached in AA5 and near-total digestion suggest that not all carbonates dissolved in AA5. The near-total digestion data indicate that the carbonates contain significant $\mathrm{Mg}$, with $\mathrm{Mg} / \mathrm{Ca}$ weight ratios ranging from 0.1 to 0.64 in the Whiskey traverse (Fig. 7). Carbonates in the background areas are mostly $\mathrm{CaCO}_{3}$ with low $\mathrm{Mg} / \mathrm{Ca}$ and they dissolved in AA5. The recovery of $\mathrm{Ca}$, ( $\mathrm{Ca}$ in $\mathrm{AA} 5) /(\mathrm{Ca}$ in near-total digestion), is high: 0.89 (W15 humus) and 0.99 (W1 B-horizon). The recoveries of $\mathrm{Ca}$ are, however, low in samples with high $\mathrm{Mg} / \mathrm{Ca}$ (Fig. 7). The data indicate that $\mathrm{Mg}$-rich carbonates do not dissolve in AA5.

High $\mathrm{Mg} / \mathrm{Ca}$ in carbonates from the areas close to the kimberlite confirm the conclusion that the carbonates are indeed secondary and that $\mathrm{Mg}$ likely originated from kimberlite because limestones hosting kimberlites contain mostly calcite,
$\mathrm{CaCO}_{3}$. This leaves a question whether a stronger leach than AA5 may show better geochemical signals of kimberlites. A further study is required to evaluate the optimal strength of the leach solution.

Anomalous concentrations of REE and other pathfinder elements in AA5 also occur outside the margins of the kimberlites (Figs. 8b \& 9). For example, several anomalous peaks of Ni occur outside the kimberlites (Figs. 8 a \& 10). There are possible causes for displaced anomalies. The study area is located within the discontinuous permafrost region where frozen blocks of soil prevent waters from moving freely. This likely contributes to the displaced anomalies because water moves around frozen blocks of ground or in thawed channels within frozen ground. Therefore, water released from kimberlites may not move upward to the surface.

There are other possible causes for the displacement of anomalies. $\mathrm{pH}$ is an important factor controlling the dissolution and precipitation of secondary phases in soils. Some of the secondary phases may host metals associated with kimberlites. To evaluate this possibility, the $\mathrm{pH}$ values of the soil slurry are plotted together with $\mathrm{Al}$ contents in AA5 for the Whiskey traverse (Fig. 8a, b). Soil slurry pH values change from 5.6 to 7.9 and $\mathrm{Al}$ contents in AA5 from 37 to $618 \mathrm{ppm}$ along the Whiskey traverse, and the $\mathrm{pH}$ and $\mathrm{Al}$ contents are inversely correlated. This is consistent with the solubility of Al, which has a minimum at $\mathrm{pH} \quad$ c. 6 and increases with increasing and decreasing $\mathrm{pH}$ because $\mathrm{Al}$ dissolves as $\mathrm{Al}^{3+}$ at lower $\mathrm{pH}$ and $\mathrm{Al}(\mathrm{OH})_{4}{ }^{-}$at higher $\mathrm{pH}$; thus, $\mathrm{Al}$ is expected to precipitate in a rather acidic $\mathrm{B}$-horizon soil in the study area. Low $\mathrm{Al}$ contents in AA5 along the Whiskey traverse and along the Yankee traverse occur over the kimberlites (Figs. 8b \& 9), suggesting that alkaline condition prevails over the kimberlites.

The contents of $\mathrm{Al}$ in AA5, over 1000 ppm, are higher than expected if $\mathrm{Al}$ is present in carbonates. These high contents of $\mathrm{Al}$ indicate that the AA5 leach dissolved not only carbonates but also amorphous Al-O-OH; it is also possible that minor amounts of fine-grained clays dissolved in AA5, since clays may dissolve in mildly acidic solution of c. 5 (Mihaljevič et al. 2006). Amorphous $\mathrm{Al}$ in soil most likely originated from disintegration of clasts, with drainage from the overlying $A_{\circ}$ during soil development. Therefore, Al contents reflect the amorphous clastic components in soil. This interpretation is supported by a positive correlation between $\mathrm{Al}$ and $\mathrm{Zr}$ in the $\mathrm{AA} 5$ leach, with a correlation coefficient $\left(\mathrm{r}^{2}\right)$ of 0.94 for Yankee and 0.57 for the Whiskey B-horizon samples. Zirconium is not soluble and is commonly used as the proxy for a clastic component in weathered rocks and soil; in addition, Zr contents are particularly high in kimberlites. The good correlation between $\mathrm{Zr}$ and $\mathrm{Al}$ in AA5 for B-horizon soil samples suggests that $\mathrm{Al}$ is indeed a clastic component, and that it should therefore be accompanied by other immobile elements. Rare earth elements are also relatively immobile during weathering and soil development (e.g. Öhlander et al. 1996). In the study area the tills have granitic fragments. Therefore, we suggest that the anomalously high REE contents outside the kimberlite likely originated from amorphous clastic components indigenous to soil. Taking the ratios of metals to $\mathrm{Al}$ in the soil leach removes the clastic component and the factors related to $\mathrm{pH}$ changes in soil, and will highlight the fluxes of exogeneous metals to the soil. Therefore, metal anomalies related to kimberlites are enhanced in the ratios of metals to $\mathrm{Al}$ (Figs. 8a, b, 9 \& 10).

\section{Enzyme leach}

Enzyme leach is aimed at dissolving metals within and adsorbed on amorphous Mn-O-OH (Clark 1993; Clark et al. 1997), but 
there are discussions as to what is dissolved in the Enzyme leach, and whether the leach dissolves metals associated with Mn-O-OH. Cohen et al. (2007) show a diagram illustrating that the Enzyme leach is a stronger leach than AA5, and that it dissolves metals in carbonates and amorphous Mn-oxides. On the other hand, Cameron et al. (2004) suggested that the Enzyme leach is similar to a pure water leach, based on the $\mathrm{Zn}$ contents in the Enzyme leach and pure water leach applied to samples from soil over the Cross Lake deposit in Timmins, and $\mathrm{Cu}$ contents in both leaches of samples over the Spence deposit in Chile. They suggested that the Enzyme leach mainly dissolves water-soluble salts in soil. Their conclusion appears to be supported by high contents of halogens in Enzyme leach solutions from many locations (e.g. Clark et al. 1997; Yeager et al. 1998) because negatively charged halogens would not be adsorbed on $\mathrm{Mn}-\mathrm{O}-\mathrm{OH}$. However, the data from the Cross Lake and Spence deposits do not reject the possibility that metals adsorbed on amorphous $\mathrm{Mn}-\mathrm{O}-\mathrm{OH}$ are leached in the Enzyme solution. Metals on the amorphous Mn-O-OH may be resorbed to an Enzyme leach in response to a change in $\mathrm{pH}$ or oxidation state during the analysis.

Our data show only small fractions of metals in soil samples dissolve in the Enzyme leach compared to metals in AA5. Therefore, the Enzyme leach appears to be a very weak leach even compared to AA5 leach. For example, REE contents in the Enzyme leach are very low compared to those in AA5. Manganese contents in the Enzyme leach vary from 0.5 to $16.5 \mathrm{ppm}$ in the Whiskey traverse (Figs. 11a, b) in contrast to 55-832 ppm Mn by near-total digestion. The $\mathrm{Mn}$ in the Enzyme leach at the Whiskey traverse corresponds to only 0.20 to $2.44 \%$ of the $\mathrm{Mn}$ in the near-total digestion. The recoveries of $\mathrm{Mn}$ in the Enzyme leach from the Yankee traverse are also low, 0.10 to $1.2 \%$ of the near-total digestion of samples. Niobium recovered in the Enzyme leach relative to the contents by near-total digestion varies from 0.04 to $0.22 \%$ at the Whiskey sites and 0.03 to $0.14 \%$ at the Yankee sites. Such low recoveries of metals suggest that the Enzyme leach may not dissolve amorphous $\mathrm{Mn}$ phases and associated metals, but is rather, simply dissolving fractions of metals that are loosely adsorbed on the surface of oxy-hydroxides. Therefore, our data do not support the interpretation by Cohen et al. (2007) that the leach dissolves reactive $\mathrm{Mn}-\mathrm{O}-\mathrm{OH}$ phases. Although the absolute concentrations of metals leached in the Enzyme leach are low, the leach appears still useful because it offers very low detection limits for many elements. Low detection limits allow anomalies of kimberlite pathfinder elements to be detected in the Enzyme leach.

The results suggest that single-element anomalies need to be carefully evaluated in any leach, as to whether the element originates from kimberlites or other sources, such as a clastic component in soil. This is necessary because the partial leach dissolves specific target phases as well as other amorphous material and poorly crystalline phases.

\section{Concentration patterns of kimberlite pathfinder elements}

Several secondary phases are important in controlling the behaviour of metals in soil, including carbonates and amorphous $\mathrm{Fe}-\mathrm{Mn}-\mathrm{O}-\mathrm{OH}$. In general, both $\mathrm{Fe}$ and $\mathrm{Mn}$ are soluble under reduced conditions as $\mathrm{Fe}^{2+}$ and $\mathrm{Mn}^{2+}$, and precipitate as oxyhydroxide under oxidized conditions. Carbonates precipitate when waters become alkaline, or where $\mathrm{CO}_{2}$ is added to the system. This input of $\mathrm{CO}_{2}$ may be in response to the oxidation of organic matter and $\mathrm{CH}_{4}$, or decompression of $\mathrm{CO}_{2}$-saturated groundwaters.
The weathering of kimberlites produces reduced gases as the hydration of olivine produces $\mathrm{CH}_{4}$ gas from $\mathrm{CO}_{2}$ and also $\mathrm{H}_{2}$ gas from $\mathrm{H}_{2} \mathrm{O}$ (e.g. Charlou et al. 1998a, b; Sleep et al. 2004). The flux of such reduced gases causes a reduced oxidation condition over kimberlites. This process is supported by the presence of abundant anaerobic bacteria above kimberlites in the study sites (G. Southam, pers. comm., 2007). It is further supported by $\mathrm{CH}_{4}$ gas discharging from diamond drill-holes that intersected several kimberlites during the field work in the summer of 2006, as well as an abundance of $\mathrm{CH}_{4}$ in laboratory analyses by Brauneder (2007). The $\mathrm{CH}_{4}$ generated during the weathering of kimberlites is readily oxidized to carbonate even at depth (e.g. Aloisi et al. 2002).

In addition, the weathering of olivine consumes $\mathrm{H}^{+}$, which results in the formation of an alkaline water, as has been clearly recorded in the Coast Range of California where abundant ultramafic rocks are present (e.g. Barnes \& O’Neil 1969). Highly alkaline waters are also reported in waters from the drill-holes that intersect kimberlites in the Kirkland Lake area (e.g. Sader et al. 2007). Therefore, weathering of kimberlites produce alkaline waters with a reduced oxidation state.

Both factors - oxidative formation of $\mathrm{CO}_{2}$ and alkaline waters - favour the precipitation of secondary carbonates above kimberlites. High concentrations around the margins of kimberlites, rather than over the centres, may be explained by a more reduced condition maintained by a high flux of reduced gases in the centre. Alternatively, the abundance of the secondary carbonates above margins of kimberlites may be related to upwelling of waters along the boundaries between kimberlites and host rocks, since fractures near the boundaries likely provide permeability for fluid flow. Kimberlite pathfinder elements with an affinity for carbonate minerals are, therefore, concentrated on the margins and just outside the areas of kimberlites where these secondary phases form; regardless of the true cause of this distribution, the empirical observation is useful for exploration.

Pathfinder elements released from kimberlites ascend in areas above kimberlites due to a variety of mechanisms. Reduced gases from the underlying kimberlite produces reduced conditions in the soil over the kimberlite, and this condition results in low $\mathrm{Mn}$ and $\mathrm{Fe}$ contents since these elements can easily change their valences at low temperatures and are soluble as reduced $\mathrm{Fe}^{2+}$ and $\mathrm{Mn}^{2+}$. Without amorphous $\mathrm{Mn}-\mathrm{Fe}-\mathrm{O}-\mathrm{OH}$, metals that have no affinity with carbonates are not easily fixed in soil directly over kimberlites. Rather, these metals are transported until they encounter reactive amorphous $\mathrm{Mn}-\mathrm{Fe}-\mathrm{O}-\mathrm{OH}$ in soil outside the area overlying kimberlites.

Displacement of anomalies of charged cations may also be explained by this redox variation over kimberlites. For example, the peak of $\mathrm{Ti}$ and $\mathrm{Ti} / \mathrm{Mn}$ occurs outside the area of the Yankee kimberlite (Fig. 13). Titanium forms a tetravalent cation and is adsorbed on Mn-Fe-O-OH. It is not easily fixed under reduced conditions, where reactive $\mathrm{Mn}-\mathrm{Fe}-\mathrm{O}-\mathrm{OH}$ is low directly over kimberlites. In addition, the study area lies in discontinuous permafrost terrain, where water movement is restricted to areas between blocks of frozen ground. Upward movement of water may not be possible near the boundary between kimberlites and host limestone.

Ratios of metals to Mn enhance the recognition of metal anomalies related to kimberlites due to the low Mn contents above kimberlites (Figs. 11-13). Therefore, ratios are not meant to determine the amount of metals in a unit amount of $\mathrm{Mn}$. Rather, the ratios combine the two factors associated with kimberlites: increased contents of kimberlite pathfinder metals and lower contents of $\mathrm{Mn}$ due to reduced conditions created by weathering of underlying kimberlites. 


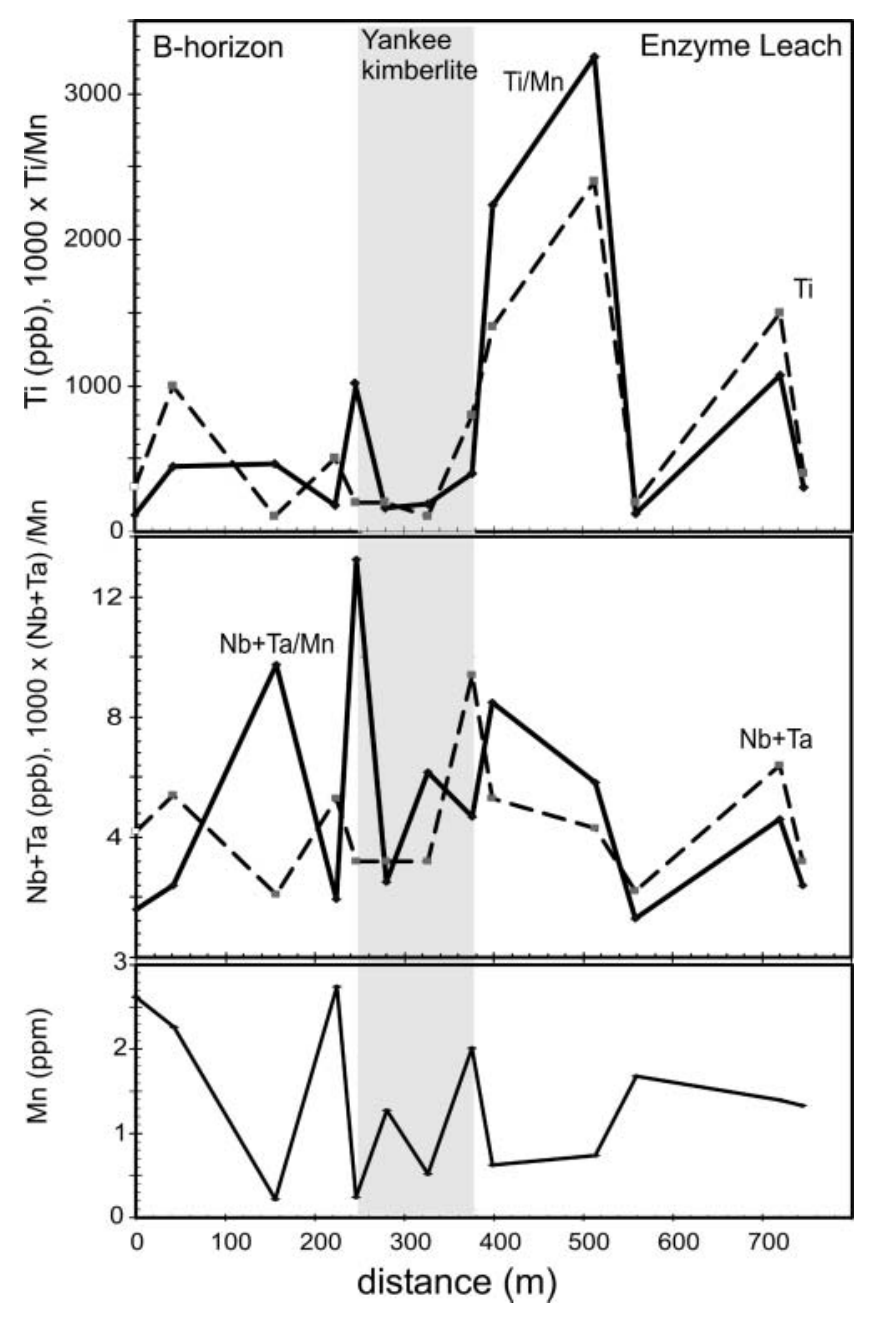

Fig. 13. Enzyme leach results over the Yankee traverse. Sum of $\mathrm{Nb}+\mathrm{Ta}$ (dashed line) and the ratios of $(\mathrm{Nb}+\mathrm{Ta}) / \mathrm{Mn}$ (upper diagram) and Ti contents (dashed line) compared to the ratios of $\mathrm{Ti} / \mathrm{Mn}$ (lower diagram).

\section{Use of geochemical data for diamond exploration}

The findings of this study explain the apparently negative and at first glance disappointing results of previous soil geochemical surveys, where workers collected soil samples in the centres of areas underlain by kimberlites, since they assumed that the largest anomalies should be over the centres of kimberlites. For example, metal contents in composite soil samples from the centres of concealed kimberlites are similar to those outside the kimberlites in the Kirkland Lake area (Burt \& Hamilton 2004). Seneshen et al (2005) and Fenton et al. (2006) also did not find geochemical anomalies in samples over the centres of kimberlites in northern Alberta.

Strong geochemical signals of kimberlites in the soils of this study are encouraging, considering that the kimberlites are overlain by clay sediments and tills. In addition the area is in the discontinuous permafrost region with short snow-free periods. At temperatures near and below the freezing point, chemical weathering of rocks is sluggish with limited amounts of liquid water. The physical dispersion of elements from kimberlites is also slow in environments where the transport medium, water, is mostly frozen. This implies that soil geochemical anomalies should be stronger in areas of warmer climate.
The topography and climate of the study area are similar to many parts of the northern countries, especially in the Hudson Bay Lowlands. Therefore, the information obtained from this study is readily transferable to a large region of the north.

At present, the most frequently used techniques during kimberlite exploration in northern glaciated countries are surveys of heavy minerals in basal unit of glacial tills combined with geophysical surveys. However, the dispersion trails of kimberlite indicator minerals are commonly greater than $50 \mathrm{~km}$ in width $100 \mathrm{~km}$ in length (e.g. Dredge et al. 1997), which defines at best a huge area of potential; dispersion trains may be complicated in the areas with several glacial events, yielding many possible kimberlite targets (e.g. Lehtonen et al. 2005).

Once a prospective region is suggested from heavy mineral surveys, aeromagnetic surveys can be effective in delineating kimberlites due to their commonly circular-shaped positive magnetic anomalies. However, such magnetic anomalies are also produced by many other rocks, such as ultramafic dykes, syenitic-monzonitic intrusions, and even magnetite-bearing granite. Furthermore, a significant number of diamondiferous kimberlites do not show positive anomalies on magnetic maps for a variety of reasons, such as magnetic host rocks and reverse magnetization (e.g. Power et al. 2004). At present, targets are tested by drilling, but drilling is costly and in many locations must wait until winter when drilling equipment can be transported to the target site using winter ice roads.

Geochemical surveys provide a cost-effective and rapid method to discriminate kimberlites from other targets defined by heavy mineral and geophysical surveys. For example, ultramafic rocks can produce geophysical anomalies similar to kimberlites, but ultramafic rocks have low contents of light REE, Y, alkalis and alkali-earth elements compared to even ordinary rocks, and thus should be easily distinguished from kimberlites. Therefore, a soil geochemical survey serves as a complementary method to existing exploration techniques, prior to final drill testing.

\section{Recommendation}

This study shows that geochemical anomalies are concentrated near the edges of concealed kimberlites. Soil samples should be collected along a traverse over a target, using a shorter sampling distance of $c .20$ to $25 \mathrm{~m}$ near the edges of the target, as typically defined by geophysical surveys. The traverse should be designed to collect similar surface media under similar surface conditions and topography.

Although we did not collect C-horizon soil to compare the results with B-horizon samples, pathfinder elements are likely concentrated in B-horizon soil samples because kimberlite pathfinder elements form cations in water. Since the common presence of $\mathrm{Fe}-\mathrm{Mn}-\mathrm{O}-\mathrm{OH}$ in the $\mathrm{B}$-horizon scavenges cations the B-horizon soil, if available, would be a better medium than C-horizon soil and humus.

Samples should be subjected to partial leach techniques, AA5 and/or Enzyme leach, as they are effective in discriminating kimberlites from other targets, but the data need to be carefully examined to consider contributions from other sources. For example, AA5 is effective in obtaining REE, Y, Ni, and $\mathrm{Mg}$, but in samples with high $\mathrm{Al}$, the contribution of any clastic component needs to subtracted. Enzyme leach is good for displaying anomalies of charged cations, such as $\mathrm{Nb}, \mathrm{Ta}$, Ti, and REE, but their single element plot may show misleading results. The ratios of metals to $\mathrm{Mn}$ may be more effective in discriminating the target. 


\section{CONCLUSIONS}

B-horizon soil, if available, is suitable as a sample medium for soil geochemical surveys during kimberlite exploration, particularly in northern countries. Amorphous Fe-Mn-O-OH, and carbonates form near the areas overlying the margins of kimberlites. The spatial relationship between the formation of these secondary phases and kimberlites suggest the presence of redox and $\mathrm{pH}$ gradients above concealed kimberlites. The occurrence of a redox gradient is explained by weathering of olivine in kimberlites that will produce an alkaline environment and reduced gases, such as $\mathrm{CH}_{4}$.

High concentrations of kimberlite pathfinder elements occur in association with secondary phases, including carbonates and $\mathrm{Fe}-\mathrm{Mn}$-oxides. Light $\mathrm{REE}, \mathrm{Y}, \mathrm{Ni}$, and $\mathrm{Mg}$ are concentrated in secondary carbonates associated with the kimberlites, whereas $\mathrm{Nb}, \mathrm{Ta}$, and $\mathrm{Ti}$ are adsorbed onto the surface of $\mathrm{Mn}-\mathrm{Fe}-\mathrm{O}-\mathrm{OH}$. Therefore, partial leach methods such as AA5 and Enzyme leach are effective at identifying anomalies associated with kimberlites, and offer a cost-effective method to help confirm the presence, prior to drilling, of a kimberlite in contrast to other features that may generate a similar geophysical target. However, such geochemical surveys require careful sampling to ensure similar media along a traverse, and cautious evaluation of data, including a consideration of elements from other sources.

Enzyme leach was carried out at Activation Laboratories Inc (Ancaster, ON, Canada). Total digestion and AA5 were carried out gratis at Acme Analytical Laboratories Ltd, Vancouver, Canada. Loss on ignition for the Whiskey samples was determined at the Geoscience Laboratory of the Ontario Geological Survey, for the Yankee samples by M. Salman at the University of Ottawa. N. Januszczak of DeBeers Canada is thanked for providing the locations of kimberlites, and ground magnetic maps of the area. The field work was assisted by G. Southam of the University of Western Ontario, and M. Al-Khafaji and K. Brauneder of the University of Ottawa. Many people at the Victor mine site, especially B. Steinback, E. Francisco, T. Ternes and B. Wood, were very helpful. We acknowledge financial support from DeBeers Canada Exploration and NSERC through the Collaborative Research Development program. This manuscript benefited comments received from two journal reviewers, E. Cameron and W. Coker, and the editor, G. Hall.

\section{REFERENCES}

Aloisi, G., Bouloubassi, I, Heijs, S.K. et al. 2002. $\mathrm{CH}_{4}$ - consuming microorganisms and the formation of carbonate crusts at cold seeps. Earth and Planetary Science Letters, 203, 195-203.

B AjC, A.F. 1998. A comparative analysis of Enzyme leach and mobile metal ion selective extractions: case-studies from glaciated terrain, northern Ontario. Journal of Geochemical Exploration, 61, 113-148.

Barnes, I. \& O’NeIL, J.R. 1969. The relationship between fluids in some fresh alpine-type ultramafics and possible modern serpentinization, western United States. Geological Society of American Bulletin, 80, 1947-1960.

Brauneder, K. 2007. Characterization of peatland waters overlying concealed kimberlites in the Attapikat region, northern Ontario. BSc thesis, University of Ottawa. Ottawa.

Burt, A.K. \& Hamitton, S.M. 2004. A comparison of selective leach signatures over kimberlites and other targets. Open File Report, 6142, Ontario Geological Survey.

Cameron, E.M., Hamilton, S.M., Leybourne, M.I., Hall, G.M. \& McClenaghan, M.B. 2004. Finding deeply buried deposits using geochemistry. Geochemistry: Exploration, Environment, Analysis, 4, 7-32.

Cave, M.R. \& Harmon, K. 1997. Determination of trace metal distributions in the iron oxide phases of Red Bed sandstones by chemometric analysis of whole rock and selective leachate data. Analyst, 122, 501-512.

Charlou, J.L., Donval, J.P., Fouquel, Y., Jean-Baptiste, P. \& Holm, N. 1998a. Geochemistry of high $\mathrm{H}_{2}$ and $\mathrm{CH}_{4}$ vent fluids issuing from ultramafic rocks at the Rainbow hydrothermal field $\left(36^{\circ} 14^{\prime} \mathrm{N}, \mathrm{MAR}\right)$. Chemical Geology, 191, 345-359.
Charlou, J.L., Fouquet, Y., Bougault, H., Donval, J.P. \& Etoubleau, J. 1998b. Intense $\mathrm{CH}_{4}$ degassing generated by serpentinization of ultramafic rocks at the intersection of the $15^{\circ} 20^{\prime} \mathrm{N}$ fracture zone and the Mid-Atlantic Ridge. Geochimica et Cosmochimica Acta, 62, 2323-2333.

Clark, J.R. 1993. Enzyme-induced leaching of B-horizon sols for mineral exploration in areas of glacial overburden. Transactions, Institute of Mining and Metallurgy, 102, B19-29.

Clark, J.R., Yeager, J.R., Rogers, P. \& Hoffman, E.L. 1997. Innovative Enzyme Leach provides cost-effective overburden/bedrock penetration. In: Gibins, A.G. (ed.) Proceedings of Exploration 97: Fourth Decennial International Conference on Mineral Exploration, Geo F/X, Toronto, 371-374.

Cohen, D.R., Kelley, D.L., Anand, R. \& Coker, W.B. 2007. Major advances in exploration geochemistry, 1998-2007. In: Milkereit, B. (ed.) Proceedings of Exploration 07: Fifth Decennial International Conference on Mineral Exploration, Toronto, 3-18.

COKER, W. 2007. Future research directions in exploration geochemistry: Is there a future? In: Milkereit, B. (ed.) Proceedings of Exploration 07: Fifth Decennial International Conference on Mineral Exploration, Toronto, 331-337.

Dredge, L.A., Kerr, D.E., KJarsgard, I.M., Knight, R.D. \& Ward, B.C. 1997. Kimberlite indicator minerals in till, central Slave Province, Northwest Territories. Open File 3426, Geological Survey of Canada.

Fenton, M.M., Pawlowicz, J.G. \& Prior, G.J. 2006. Geochemical soil survey over the K4B kimberlite, Buffalo Head Hills, northern Alberta. Geo-Note 2005-09, Alberta Geological Survey, Alberta.

Filipek, L.H. \& Theobald, P.K. Jr. 1981. Sequential extraction techniques applied to a porphyry copper deposit in the Basin and Range Province. Journal of Geochemical Exploration. 14, 155-174.

FiPke, C.E., Gurney, J.J. \& Moore, K.O. 1995. Diamond exploration techniques emphasizing indicator mineral geochemistry and Canadian examples. Geological Survey of Canada Bulletin, 423.

Fowler, J.A., Grutter, H.S., Kong, J.M. \& Wood, B.D. 2001. Diamond exploration in northern Ontario with reference to the Victor kimberlite, near Attawapiskat. Exploration Mining Geology, 10, 67-75.

Gray, D.J., Wildman, J.E. \& Langman, G.D. 2001. Selective and partial extraction analyses of transported overburden for exploration in the Yilgarn craton and its margins. Open File Report 107, Cooperative Research Centre for Landscape Evolution \& Mineral Exploration, Canberra, Australia.

Hamilton, S.M. 1998. Electrochemical mass-transport in overburden: A new model to account for the formation of selective-leach geochemical anomalies in glacial terrain. Journal of Geochemical Exploration, 63, 155-172.

Heiri, O., Lotter, A.F. \& Lemcke, G. 2001. Loss of ignition as a method for estimating organic and carbonate content in sediments: reproducibility and comparability of results. Journal of Paleolimnology, 25, 101-110.

Kelley, D.L., Hall, G.E.M., Closs, L.G., Hamilton, I.C. \& McEwen, R.M. 2004. The use of partial extraction geochemistry for copper exploration in northern Chile. Geochemistry: Exploration, Environment, Analysis, 3, 85-104.

Kelley, D.L., Kelley, K.D., Coker, W.B., Caughlin, B. \& Doherty, M.E. 2006. Beyond the obvious limits of ore deposits: the use of mineralogical, geochemical, and biological features for the remote detection of mineralization. Economic Geology, 101, 729-752.

KLEIN, E.M. 2005. Geochemistry of the igneous oceanic crust. Treatise on Geochemistry, 3, 433-463.

Lehtonen, M.L., Marmo, J.S., Nissinen, A.J., Johanson, B.S. \& Pakkanen, L.K. 2005. Glacial dispersal studies using indicator minerals and till geochemistry around two eastern Finland kimberlites. Journal of Geochemical Exploration, 87, 19-43.

Luo, Y-R \& Byrne, R.H. 1998. Carbonate complexation of yttrium and rare earth elements in natural waters. Geochimica et Cosmochimica Acta, 68, 691-699.

McClenaghan, M.B., Thorleifson, L.H. \& Dilabio, R.N.W. 2000. Till geochemical and indicator mineral methods in mineral exploration. Ore Geology Review, 16, 145-166.

McClenaghan, M.B., Hamilton, S.M., Hall, G.E.M., Burt, A.K. \& KJARSGAARD, B.A. 2006. Selective leach geochemistry of soils overlying the 95-2, B30 and A4 kimberlites, northeastern Ontario. Open File 5069, Geological Survey of Canada, Ottawa, Canada.

McDonough, W.F. \& Sun, S.S. 1995. The composition of the Earth. Chemical Geology, 120, 223-253.

Mihaljevič, M., Etтtler, V, Hradil, D., Šebek, O. \& Strnnad, L. 2006. Dissolution of bentonite and release of rare earth elements at different solid/liquid ratios in a simulated wine purification process. Applied Clay Science, 31, 36-46.

Mrtchell, R.H. 1986. Kimberlites: Mineralogy, Geochemistry and Petrology, Plenum Publishing, New York. 
Öhlander, B., Land, M., Ingri, J. \& Widerlund, A. 1996. Mobility of rare earth elements during weathering of till in northern Sweden. Applied Geochemistry, 11, 93-99.

Power, M., Belcourt, G. \& Rockel, E. 2004. Geophysical methods for kimberlite exploration in northern Canada. The Leading Edge, (November), $1124-1129$.

Sader, J.A., Leybourne, M.I., McClenaghan, M.B. \& Hamilton, S.M. 2007. Low-temperature serpentinization processes and kimberlite ground water signatures in the Kirkland Lake and Lake Timiskiming kimberlite fields, Ontario, Canada; implications for diamond exploration. Geochemistry: Exploration, Environment, Analysis, 7, 3-21.

Seneshen, D.M., Grunsky, E.C., Rencz, A., Hall, G.E.M. \& Dunn, C.E. 2005. Geochemical Orientation Surveys (Fiscal Year 2000-2001) for kimberlites in Northern Alberta. Earth Sciences Report 2005-01, Alberta Geological Survey, Edmonton, Canada.

Sleep, N.H., Meibom, A., Fridriksson, Th, Coleman, R.G. \& Bird, D.K. 2004. $\mathrm{H}_{2}$-rich fluids from serpentinitation: Geochemical and biotic implications. Proceedings of Association of Science, 101, 12,818-12,823.
SMEE, B.W. 1998. A new theory to explain the formation of soil geochemical responses over deeply covered gold mineralization in arid environments. Journal of Geochemical Exploration, 61, 149-172.

TAYLOR, S.R. \& McLennan, S.M. 1995. The geochemical evolution of the continental crust. Reviews in Geophysics, 33, 241-265.

Webb, K.J., Smith, B.H.S., Paul, J.L. \& Hetman, C.M. 2004. Geology of the Victor kimberlite, Attawapiskat, Northern Ontario, Canada: Cross-cutting and nested craters. Lithos, 76, 29-50.

WAKEFIELD, S.J. 1980. Geochemical studies on the leaching of metalliferous sediments from the East Pacific. Journal of Geological Society, London, 137, 379-380.

Williams, T.M. \& Gunn, A.G. 2002. Application of Enzyme leach soil analysis for epithermal gold exploration in the Andes of Ecuador. Applied Geochemistry, 17, 367-385.

Yeager, J.R., Clark, J.R., Mitchell, W. \& Renshaw, R. 1998. Enzyme leach anomalies associated with deep Mississippi Valley-type zinc ore bodies at the Elmwood Mine, Tennessee. Journal of Geochemical Exploration, 61, 103-112.

Received 25 March 2008; revised typescript accepted 23 July 2008. 